\title{
個別要素法と流れの数値解析を組み合わせた 高濃度平衡流砂場の数値実験 \\ NUMERICAL SIMULATION ON A FULLY DEVELOPED SEDIMENT- MIXTURE FLOWS BY USING A DEM-FLOW COUPLING MODEL
}

\author{
清水義彦 1 若井明彦 2 ・長田健吾 3 \\ Yoshihiko SHIMIZU, Akihiko WAKAI and Kengo OSADA

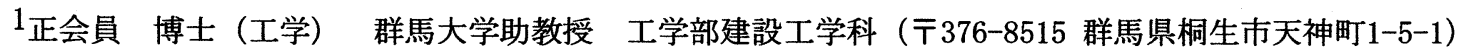 \\ 2 正会員 博士 (工学) 群馬大学助教授 工学部建設工学科 ( $376-8515$ 群馬県桐生市天神町 $1-5-1$ ) \\ 3 学生会員 群馬大学大学院工学研究科博士前期過程（テ376-8515 群馬県桐生市天神町1-5-1)
}

\begin{abstract}
Many traditional researches on the sediment mixture flow are based on the continuum mechanics, which handled with water and particles as one body. But this method can not describe the particle/particle interaction based on dynamical mechanism of particle motions. This study takes an approach method for considering particles motion and motion of water current individually by using the distinct element method (DEM) coupled with k- $\varepsilon$ turbulence model for water-flow. The flow velocity profile and the concentration profile are calculated and compared with the reported experimental results. And the internal structure of the sediment-water mixture flow and the role of momentum transfer have been investigated from the present numerical model.
\end{abstract}

Key Words : Distinct Element Method, sediment mixture flow, $k-\varepsilon$ turbulence model, motion of particles, velocity profile, concentration profile, numerical simulation

\section{1.はじめに}

従来，土石流を含む流砂に関する多くの研究は混相流 としての扱いによる連続体力学の観点からなされ，数多 くの成果が得られてきた ${ }^{1)}$. 一方, 後藤らは流体系 (連続 系) と粒子系(離散系)の相互干渉を組み込んだEulerLangrangeカップリングモデルを構筑し2)，3)，なかでも, 粒子群の衝突までを考慮できる個別要素法（Distinct Element Method；DEM） ${ }^{4)}$ と流体計算を組み込んだ数値 モデルを提案して, 流体・粒子間, 粒子間の相互干渉が 掃流砂の流砂構造に及ぼす影響を検討している ${ }^{3)}$. 粒子 の個別運動過程はsaltation等の研究に見られるように粒 子の運動方程式にもとづく解析が従来よりなされてきた が，多粒子群を対象に粒子間衝突を直接考慮できる流砂 の運動解析は後藤らによってはじめてなされ $\left.{ }^{5)}, 6\right)$, 最 近では，混合砂の流送や動的粗粒化といった流砂過程の 解析にも適用し，その有効性を示している7 $\left.{ }^{7}, 8\right)$. 本研 究でもDEMとオイラ一的流体解析を組み合わせた後藤 ら ${ }^{3)}$ と同様なフレームワークで, 掃流力の高い平衡流砂 場における流砂過程を考察する. すなわち, 個々の粒子 運動は, 掃流力増加とともに流砂濃度を増すため, 粒子
間衝突といった事象が運動過程に適切に反映されねばな らない. こうした事象を受けて決まる粒子速度と, 流速 との相対速度によって抗力が産まれ，その反作用が流速 場における形状抵抗となる. 粒子形状抵抗の流体場への 取り込みは，清水ら ${ }^{9)}$, 辻本ら ${ }^{10)}$ が植生流れで展開し た格子内空間平均されたレイノルズ方程式によって表現 する. 数值計算対象は, 伊藤 ${ }^{11)}$ の固定床上高濃度流れ の実験とし, 流速場, 濃度場の対応とともに, 応力分担 の構造についても考察し, 高濃度平衡流砂場の構成則を 検討する上でのモデルの有效性について議論する.

\section{2. 高濃度平衡流砂場の既往研究と本研究の立場}

粒子固体と流体との高濃度混相流を対象とした研究は, Bagnoldの研究 ${ }^{12)}$ を端緒として多くのものがある. Bagnoldは, ニュートン流体と固体粒子との混合流れに おいて, 粒子運動の活発な慣性領域での応力分担は粒子 衝突あるいは接触による貢献が大きく, 流体部分の担う せん断応力は無視し得ると考えた。こうした考えは, 高 橋 $^{13)}$ ，椿ら ${ }^{14)}$ によっても支持され，この仮定に立脚 して流速分布則・濃度分布則が導かれている. 一方, 橋 
本ら ${ }^{15)}$ は，内部応力を水流のレイノルズ応力と粒子間 応力とし, 江頭ら ${ }^{16) ， 17)}$ は, 粒子摩擦(粒子骨格構造 にもとづくクーロン摩擦), 粒子の非弾性衝突, 粒子間 隙空間に占める乱流場の，3つのエネルギー散逸機構か ら内部応力を規定して流速分布則や濃度分布則を求めて いる. とくに, 江頭らは，衝突に伴う動的圧力（法線方 向応力）は宮本の研究 ${ }^{18)}$ を踏襲し（形式的にはBagnold タイプと同様），クーロン摩擦を定式化する際の粒子骨 格応力も前者の衝突に伴う動的圧力に比例するとの仮定 を設けている.この仮定は，その後，濃度分布のべき乗 則（粒子骨格応力のみで受け持たれる粒子静止層の粒子 濃度と接続する形式）として規定できるとしている ${ }^{19)}$

以上の研究から, 粒子摩擦, 粒子衝突, 流体場の乱れ が，高濃度流砂の素過程として重要であることが分るが， こうした素過程にもとづく応力算出においては，上下層 2 層での理想化された粒子配列や単純化された相対運動 が仮定されており, 高濃度であれば粒子群の不規則運動 のもとでの衝突機会も増大するため, こうした仮定がど こまで許されるかは保証できない，また，計算結果によ れば ${ }^{19)}$ ，粒子摩擦による応力分担が，流体乱れ，粒子 衝突による応力分担に比べてきわめて大きいいものの, これを検証する材料にそしいのが現状である.

本研究で, 採用したDEMとオイラー的流体解析の カップリング手法では, 従来, 曖昧であった粒子運動を 粒子摩擦, 粒子の非弾性衝突を表現できる力学的枠組み の中で捉えることができる点に最大のメリットがある. すなわち, 衝突事象を組み込みながら多粒子群の追跡が 可能で, 流体解析と連立することで粒子群の空間平均構 造が求められる. もちろん, よく指摘されるように, DEM自身には粒子運動を規定する幾つかのパラメタが 含まれ, 現段階で, 本手法のみでは高濃度平衡流砂場の 構成則を予測するものではないが，既往の水理実験と照 らし合わせることで, 実験計測からは抽出が困難な場の 特性を見出す数值実験ツールとしての有効性を提示する.

\section{3. 数値モデルの構成}

\section{(1) DEMによる粒子運動の記述}

DEMでは ${ }^{4)}$ ，剛体要素と見なした粒子間の力の伝達 が粒子接触点を介して行われるものとして，各粒子ごと の運動方程式を前進差分で解き, 時々刻々と変化する粒 子の位置を求めている．粒子間接触面における法線方向 の力 $\mathrm{f}_{\mathrm{n}}$ と接線方向の力 $\mathrm{f}_{\mathrm{s}}$ は, それぞれ接触してから の相対変位量に比例する抗力（e）(バネモデル)と相対速 度に比例する粘性抵抗力（d）（ダッシュポットモデ ル）から構成する.

$$
f_{n}=e_{n}^{t}+d_{n}=e_{n}^{t-1}+k_{n} \Delta u_{n} \Delta t+\eta_{n} \Delta u_{n}
$$

$$
\mathrm{f}_{\mathrm{s}}=\mathrm{e}_{\mathrm{s}}^{\mathrm{t}}+\mathrm{d}_{\mathrm{s}}=\mathrm{e}_{\mathrm{s}}^{\mathrm{t}-1}+\mathrm{k}_{\mathrm{s}} \Delta \mathrm{u}_{\mathrm{s}} \Delta \mathrm{t}+\eta_{\mathrm{s}} \Delta \mathrm{u}_{\mathrm{s}}
$$

ここに, $\mathrm{t}$ : 時間, 添え字の $\mathrm{n}, \mathrm{s}$ は接触面における法線, 接線方向を意味し， k はバネ定数， $\eta$ はダッシュポット 粘性係数， $\Delta \mathrm{u}$ は粒子ij の相対速度である． $\mathrm{f}_{\mathrm{s}}$ を構成す る接線方向バネ力については，一定以上の力 $\left(\tau_{\mathrm{f}}\right)$ が 働けば滑動する条件を与えた。

$$
\mathrm{e}_{\mathrm{s}}^{\mathrm{t}}=\operatorname{sign}\left(\tau_{\mathrm{f}}\right) \quad\left(\left|\mathrm{e}_{\mathrm{s}}^{\mathrm{t}}\right| \geq \tau_{\mathrm{f}}\right)
$$

$\tau_{\mathrm{f}}$ は粒子レベルのせん断強度で, クローン摩擦が適用 できるとした（c：粒子レベルの粘着力， $\phi$ : 粒子レベ ルの内部摩擦角）。

$$
\tau_{\mathrm{f}}=\mathrm{c}+\mathrm{e}_{\mathrm{n}} \tan \phi
$$

上記の粒子間干渉力（着目粒子iに接触するすべての粒 子jからの作用力の総和）と，粒子に作用寸る重力，流 れから受ける駆動力を組み込んだ粒子 $\mathrm{i}$ の運動方程式 （並進および回転）は次式のように書ける.

$$
\begin{aligned}
& m_{i}^{\prime} \frac{d u_{p i}}{d t}=\sum_{j}\left[-f_{n} \cos \alpha_{i j}+f_{s} \sin \alpha_{i j}\right]_{j} \\
& +\frac{1}{2} \rho C_{D} A_{2} d^{2} \sqrt{\left(u-u_{p i}\right)^{2}+\left(v-v_{p i}\right)^{2}}\left(u-u_{p i}\right) \\
& +\left(m_{i}-\rho V_{i}\right) g \sin \theta \\
& m_{i}^{\prime} \frac{d v_{p i}}{d t}=\sum_{j}\left[-f_{n} \sin \alpha_{i j}-f_{s} \cos \alpha_{i j}\right]_{j} \\
& +\frac{1}{2} \rho C_{D} A_{2} d^{2} \sqrt{\left(u-u_{p i}\right)^{2}+\left(v-v_{p i}\right)^{2}}\left(v-v_{p i}\right) \\
& -\left(m_{i}-\rho V_{i}\right) g \cos \theta \\
& I \frac{d \omega_{p i}}{d t}=\frac{d}{2} \sum_{j}\left[f_{s j}\right]_{j}
\end{aligned}
$$

ここに, $m_{i}^{\prime}=\rho\left[\sigma / \rho+C_{M}\right] A_{3} d^{3}, \rho:$ 流体密度, $\sigma:$ 粒 子密度, $\mathrm{C}_{\mathrm{H}}$ : 付加質量係数 $(=0.5), \mathrm{A}_{2}, \mathrm{~A}_{3}$ : 粒子の 2 次 元, 3次元形状係数, $d$ : 粒子径, $u_{\mathrm{pi}}, \mathrm{v}_{\mathrm{pi}}$ : 粒子の流下 . 鉛直速度, $\mathrm{u}, \mathrm{v}$ ：水流の流下 - 鈆直速度, $\mathrm{C}_{\mathrm{D}}$ : 抗力倸数, $\mathrm{m}_{\mathrm{i}}$ : 粒子質量, $\mathrm{V}_{\mathrm{i}}$ : 粒子体積, $\mathrm{g}$ : 重力加速度, $\mathrm{I}$ : 慣性 モーメント， $\omega_{\mathrm{pi}}:$ 粒子 $\mathrm{i}$ の回転速度である.

\section{（2）粒子運動を取り込んだ流体解析}

流体中に存在する粒子群は, 流体にとって相対速度を もつ離散的粗度としての役割をもつため, 抗力の反力を 生じ, 運動量変化を産む. この構造は, 清水ら ${ }^{9)}$ が植生 流れで取り込んだように粗度群を含む格子スケールで空 間平均されたレイノルズ方程式を適用寸れば表現できる. 
流体の乱れによる運動量混合は粒子群による抗力反力の 仕事による乱れエネルギーの生成, 逸散を取り込んだ $\mathrm{k}$ - $\varepsilon$ モデルで表現すれば9），次式の方程式系が粒子運動 を取り込んだ流体場の基礎式として得られる. こうした 取扱いは辻本ら ${ }^{10)}$ が飛砂の運動と風の解析で用い，そ の有効性を示している。

$$
\begin{aligned}
& u \frac{\partial v}{\partial x}+v \frac{\partial v}{\partial y}=-g \cos \theta-\frac{1}{\rho} \frac{\partial P}{\partial y}+\frac{\partial}{\partial x}\left(-\overline{u^{\prime} v^{\prime}}\right)+\frac{\partial}{\partial y}\left(-\overline{v^{\prime 2}}\right) \\
& +v\left(\frac{\partial^{2} v}{\partial x^{2}}+\frac{\partial^{2} v}{\partial y^{2}}\right)-\frac{v_{g}}{\rho} D_{y} \\
& u \frac{\partial u}{\partial x}+v \frac{\partial u}{\partial y}=g \sin \theta-\frac{1}{\rho} \frac{\partial P}{\partial x}+\frac{\partial}{\partial x}\left(-\overline{u^{\prime 2}}\right)+\frac{\partial}{\partial y}\left(-\overline{u^{\prime} v^{\prime}}\right) \\
& +v\left(\frac{\partial^{2} u}{\partial x^{2}}+\frac{\partial^{2} u}{\partial y^{2}}\right)-\frac{v_{g}}{\rho} D_{x} \\
& D_{x}=\frac{1}{2} \rho C_{D} A_{2} d^{2}\left(u-u_{p}\right) \sqrt{\left(u-u_{p}\right)^{2}+\left(v-v_{p}\right)^{2}} \\
& D_{y}=\frac{1}{2} \rho C_{D} A_{2} d^{2}\left(v-v_{p}\right) \sqrt{\left(u-u_{p}\right)^{2}+\left(v-v_{p}\right)^{2}} \\
& \mathrm{u} \frac{\partial \mathrm{k}}{\partial \mathrm{x}}+\mathrm{v} \frac{\partial \mathrm{k}}{\partial \mathrm{y}}=\frac{\partial}{\partial \mathrm{x}}\left[\left(v+\frac{v_{\mathrm{t}}}{\sigma_{\mathrm{k}}}\right) \frac{\partial \mathrm{k}}{\partial \mathrm{x}}\right]+\frac{\partial}{\partial \mathrm{y}}\left[\left(v+\frac{v_{\mathrm{t}}}{\sigma_{\mathrm{k}}}\right) \frac{\partial \mathrm{k}}{\partial \mathrm{y}}\right] \\
& +P_{k}+P_{f}-\varepsilon \\
& \mathrm{u} \frac{\partial \varepsilon}{\partial \mathrm{x}}+\mathrm{v} \frac{\partial \varepsilon}{\partial \mathrm{y}}=\frac{\partial}{\partial \mathrm{x}}\left[\left(v+\frac{v_{\mathrm{t}}}{\sigma_{\varepsilon}}\right) \frac{\partial \varepsilon}{\partial \mathrm{x}}\right]+\frac{\partial}{\partial \mathrm{y}}\left[\left(v+\frac{v_{\mathrm{t}}}{\sigma_{\mathrm{\varepsilon}}}\right) \frac{\partial \varepsilon}{\partial \mathrm{y}}\right] \\
& +\frac{\varepsilon}{k}\left(c_{1} P_{k}+c_{f 2} P_{f}-c_{2} \varepsilon\right) \\
& P_{k}=v_{g}\left(D_{x} u+D_{y} v\right) \\
& P_{k}=v_{t}\left[2\left\{\left(\frac{\partial u}{\partial x}\right)^{2}+\left(\frac{\partial v}{\partial y}\right)^{2}\right\}+\left(\frac{\partial u}{\partial y}+\frac{\partial v}{\partial x}\right)^{2}\right] \\
& v_{\mathrm{t}}=\mathrm{C}_{\mu} \frac{\mathrm{k}^{2}}{\varepsilon}
\end{aligned}
$$

ここに, 流下・鉛直座標を $\mathrm{x}, \mathrm{y}$ とし $, \mathrm{u}, \mathrm{v} ： \mathrm{x}, \mathrm{y}$ 方向の平 均流速成分, $\mathrm{u}_{\mathrm{p}}, \mathrm{v}_{\mathrm{p}}: \mathrm{x}, \mathrm{y}$ 方向の粒子速度成分, $\mathrm{P}$ : 静水 圧からの偏差分, $\theta$ : 水路勾配角, $\mathrm{k}, \varepsilon$ : 乱れエネル ギーとその逸散率, $v_{\mathrm{t}}$ ：渦動粘性係数， $v$ ：動粘性 係数, $v_{\mathrm{g}}$ : 後述する粒子数密度で, 粒子場の計算から 与えられる.

k- $\varepsilon$ modelのパラメタは標準值とし, 粗度抗力に係わ るパラメタ值は清水らの值を援用している ${ }^{9)} \quad\left(\mathbf{c}_{\mu}\right.$ $\left.=0.09, c_{1}=1.44, c_{2}=1.92, \sigma_{k}=1.0, \sigma_{\varepsilon}=1.3, c_{f 2}=1.3 c_{1}\right)$.

\section{(3)平街流砂場の計算の枠組み}

数值実験の対象としたものは, 伊藤 ${ }^{11}$ によっってなさ れた固定床上のガラスビーズ（径 $\propto=0.237 \mathrm{~cm} ）$ と水の混 合流れの実験で，水路勾配を $19^{\circ}$ とし水路上流端から定 常給水，給砂を行っている．無次元掃流力の範囲は1.0 ～1.4（水深 h の範囲は約1. $1 \mathrm{~cm} \sim 1.4 \mathrm{~cm}$ ） にある土石流 相当の急勾配流砂流である. 計算領域長さ $(L / h=30 ; L$ : 流下方向計算領域長さ）で計算した流速・粒子場をさら に発達させるため, 流下方向周期境界を課して平衡場を 求めた．流速・粒子場の計算では，はじめに流速場を解 き，その流速場での粒子場を求めて，次ステップでの流 速・粒子場を更新する手順を繰り返している．粒子場で の計算時間刻み $\Delta \mathrm{t} 10^{-6} \mathrm{sec}$ で，数值計算で投入する粒 子数は伊藤の実験での流砂量に等しくなるように決めた。 計算での河床条件として, 同じガラスビーズを貼り付け た粗面固定床としている.

採用したDEMパラメタ值は，対象とする掃流力範用で の粒子挙動に関する情報がないため，掃流力レベルを下 げたsaltation等の流砂運動や粒子反発に関する既往実験 報告と対応するように決めている（ $k_{n}=100 \mathrm{~N} / \mathrm{cm}$, $\mathrm{k}_{\mathrm{s}}=5 \mathrm{~N} / \mathrm{cm}, \quad \eta_{\mathrm{n}}=0.0022 \mathrm{Ns} / \mathrm{c}, \quad \eta_{\mathrm{s}}=0.0002 \mathrm{Ns} / \mathrm{cm}, \quad \mathrm{c}=0, \phi$

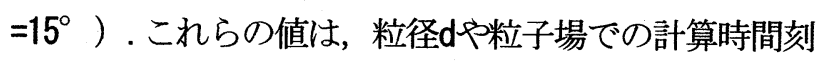
み $\Delta \mathrm{t}$ にも依存するため, 系統的な試行数值実験にもと づく力学的な考察が必要であるが本研究ではそこまで 至っていない.

濃度場は後藤ら ${ }^{5}$ ) と同様に, 粒子数密度（流体の単位 体積あたりに存在する粒子数）を $v_{\mathrm{g}}$ として, 検査面積 ( $\mathrm{L} \Delta \mathrm{y}, \Delta \mathrm{y}$ : 高さ幅) における粒子部分総面積（ $\Sigma$ $A_{p i}$ ) を求め, 次式から与えられる.

$$
v_{\mathrm{g}}=\frac{\sum \mathrm{A}_{\mathrm{pj}}}{\mathrm{L} \Delta \mathrm{y}} \frac{1}{\mathrm{~A}_{2} \mathrm{~d}^{3}}
$$

このとき, 流砂濃度 $\mathrm{C}$, 流砂量 $\mathrm{q}_{\mathrm{B}}$ は次式から与えられ る.

$$
\begin{aligned}
& C(y)=\frac{\sum A_{p i}}{L \Delta y \cdot} \frac{A_{3}}{A_{2}} \\
& q_{B}=\int C(y) u_{p} d y=\int v_{g} A_{3} d^{3} u_{p} d y
\end{aligned}
$$




\section{4. 計算結果の考察}

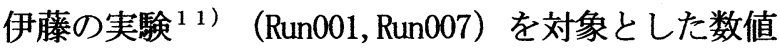
計算結果を以下に示す，図一1は，計算された流速，粒子 速度の鉛直分布である. 伊藤の実験では流速分布が計測 されているので，その対応も示した（図中○印）. 粒子 速度も流速分布にほぼ追随した分布形のせん断流タイプ となっている. ただし，流速值と粒子速度との差が本質 的に重要で, 流速場の運動量欠損分が粒子運動の運動量 増加（駆動力）となる流体・粒子系の相互作用がこれに よって生まれる.

図-2は粒子数密度（流体の単位体積あたりに存在する 粒子数）から計算された濃度分布C（印）印ある. Run007では, 水面方向に向かって減少する分布形となる が, Run001では水深にわたって一様化する傾向も認めら れる.これらのケースについて, 伊藤 ${ }^{11}{ }^{1)}$ はサンプラー を用いた局所輸送濃度を計測して求めているため, この 值も併せて表示した（図中の一点破線が測定值範囲を示 す）. 局所輸送濃度はサンプラー流入口の幅（高さ方 向）で積分された濃度值を示寸もので, 水深が薄い場合， 計測点が少なく分布を与える精度まであるかの疑問は残 るが，Run001では計算值との対応は悪くないものの， Run007では必ずしも傾向は一致しない.

図-3は，粒子運動軌跡の様子を示した一例である（見 やすくするため 3 粒子の軌跡で表現）。粒子は高さ方向 でのある層に留まらず，全水深にわたる粒子群の運動が 盛んに行われる．とくに，注目すべきことは，粒子衝突 による運動軌跡変化が頻繁に生じ, Bagnold ${ }^{12)}$, 高橋 ${ }^{1}$ 3)，椿ら ${ }^{14)}$ が土石流研究で支持したように，粒子衝突 事象の役割が大きい. 図-4は, 粒子衝突事象の高さ方向 確率密度分布であり, 衝突は $1 / 3$ 水深程度の高さで顕著 な分布となっている，こうした特徴はDEMを用いずに粒 子間衝突を反発モデルから表現した後藤ら ${ }^{20)}$ のモデル によっても記述されており，モデル表現は異なっても対 応する結果が得られることは興味深い.

次に，流体場における内部応力構造について考察する 解析ではk- $\varepsilon$ モデルを採用しているため, 流体場の乱れ 速度相関量（レイノルズ応力）までは議論することが可 能である. 図-5に計算されたレイノルズ応力（口印， / $\rho$ で表示) を示す. 平衡流れ場の応力構造を理解しや すいように，鈆直2次元場（等流）における単位幅当た りの体積 $\delta \mathrm{x} \delta \mathrm{y}$ をもつコントロールボリュウムでの力の 釣り合いを考えると，次式が成り立つ.

$$
\begin{aligned}
& {\left[\left(\tau+\frac{d \tau}{d y} \delta y\right)-\tau\right] \delta x+\left(\rho g \sin \theta-F_{p}\right) \delta x \delta y=0} \\
& \frac{d \tau}{d y}+\left(\rho g \sin \theta-F_{p}\right)=0
\end{aligned}
$$

これを水面で $\tau=0$ として $\mathrm{y}=\mathrm{h}$ からyまで積分すると次 式となる.

$$
\tau(y)=\rho g \sin \theta(h-y)-\int_{y}^{h} F_{p} d y
$$

ここに, $F_{\mathrm{p}}=v_{\mathrm{g}} \sqrt{D_{\mathrm{x}}^{2}+D_{\mathrm{y}}^{2}} \cong v_{\mathrm{g}} \sqrt{D_{\mathrm{x}}^{2}}$ で粒子群による形状抵 抗， は流体場の乱れでありレイノルズ応力に相当する. 式 (22) は, レイノルズ応力 $\tau$ と形状抵抗F作関する積 分值の加算値はいわゆる直線分布（等流）になることを 示している. そこで, 数值計算結果から求めたレイノル ズ応力分布と形状抵抗積分值の加算値 ( 併示すると，直線分布となり式(22) と矛盾しない. 同図 に伊藤の実験条件（水樑と河床勾配）から決まる直線分 布(実線)も加えて示すと, 計算值との対応は良く, 流体 場の応力関係が式(22)をもって構成されていることが分 る.

粒子群の形状抵抗Fpは，式(10)，(17)に見るように， 粒子存在数密度（濃度）と粒子速度に依存する. 粒子摩 擦, 粒子の非弾性衝突の効果は, 本研究で採用した数值 解析のフレームワークから分るように, 粒子運動として 評価されそれが形状抵抗となって流体場に組み込まれる. こうした力学的な見通しのよさが解析方法の特徴である. 混合流体系で構成した一連の土石流の既往研究ははじ め応力構造の内訳まではなかなか議論できす, 流体場の 乱れを無視し，衝突応力のみ考慮したものであった ${ }^{12) ，}$ 13）, 14）。しかし, その後, 江頭らの研究 16)，17，1 9) では内部応力の分担を理論的に取り込みながら, 粒子 摩擦(粒子骨格構造にもとづくクーロン摩擦), 粒子の非 弾性衝突，粒子間隙空間に占める乱流場の，3つのエネ ルギー散逸機構から構成則を考察し示唆に富む成果を上 げている. ただし，応力構造への流体乱れの貢献は小さ く, 粒子骨格構造にもとづく応力構造が支配的とする点 19) など, 本数值実験から推定される結果と相違してい る面もある. もちろん，モデル構成の枠組みが異なるの で結論を急ぐことは早計であり，詳細な水理実験計測の 蓄積とともに本研究で採用した数值実験の系統的な結果 整理，混合流体モデル構成とのすり合わせによって，高 濃度平衡流砂場の構成則理解を進める必要がある.

\section{5. あとがき}

本論文では，DEMとオイラ一的流体解析を連成させ た解析手法により粒子流の平衡流動数值実験を行った. このシミュレーションのフレームワークは後藤ら ${ }^{3)}$ が構 築したものと同じである. 本研究は, それを土石流を対 象とするような掃流力の高い高濃度場に適用し, 既往の 実験報告と照らし合わせることで，複雑な場の解明を試 みようとした数值実験である. その結果，平均的な構造 は実験結果とある程度対応し, 実験からは抽出しにくい 

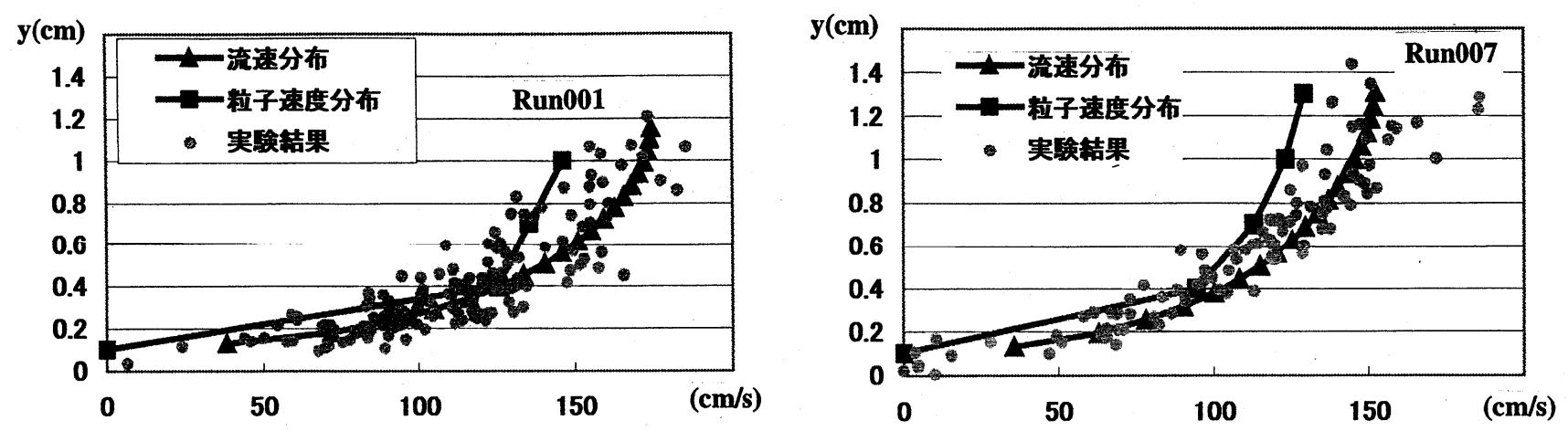

图-1 計算流速 $(\boldsymbol{\Delta}) \cdot$ 粒子速度 $(\boldsymbol{\square})$ と伊藤の実験（の）との比較
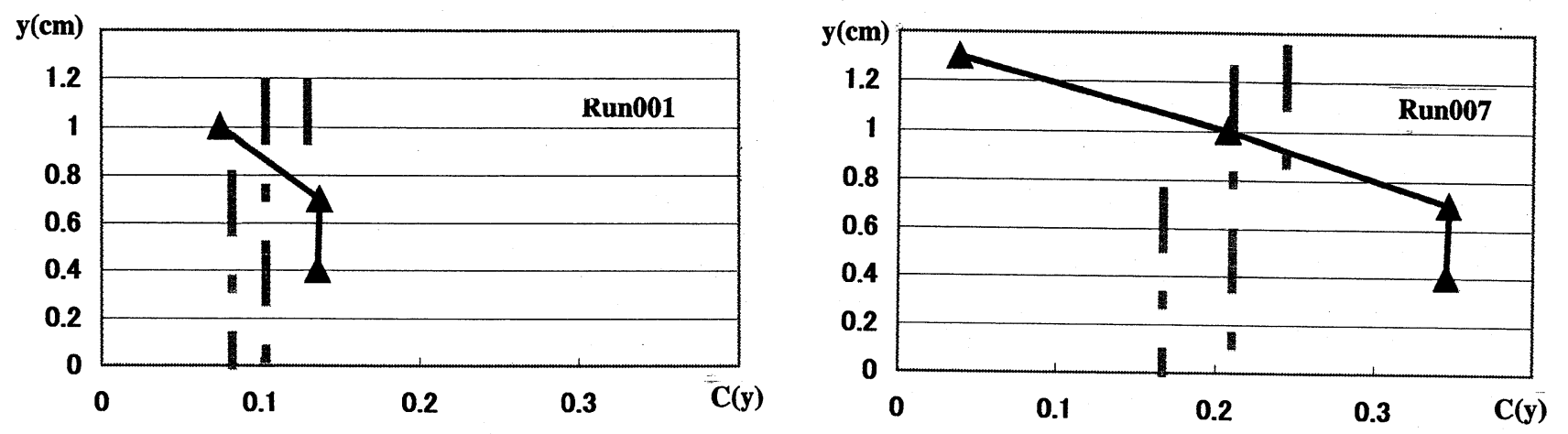

図-2 計算濃度分布（ $\Delta$ ）と伊藤の実験(実線)との比較
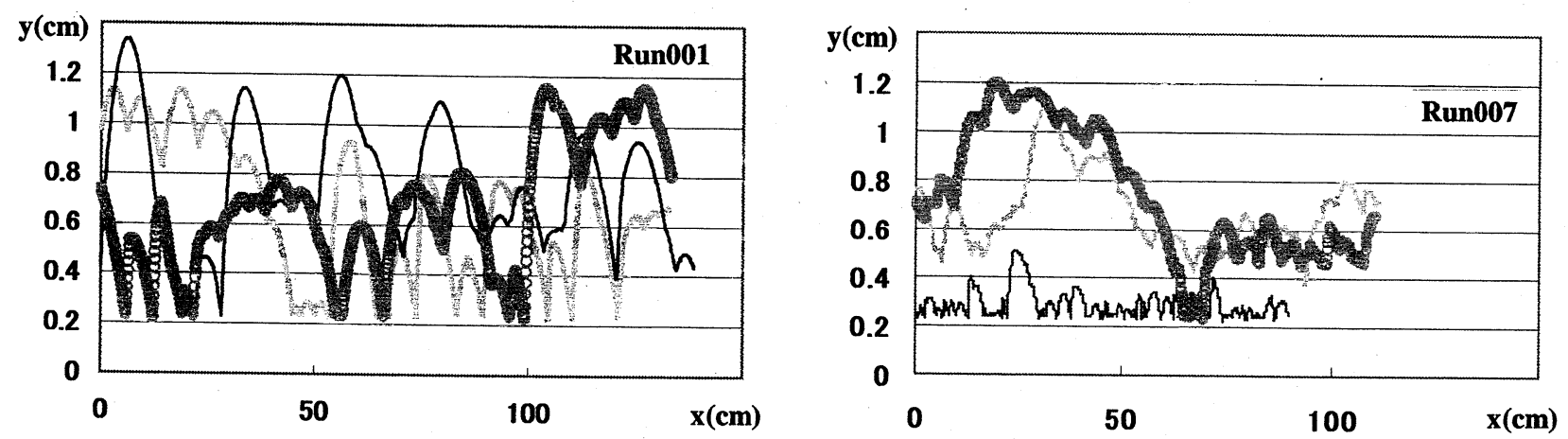

図-3 流体中の計算粒子移動軌跡（3 粒子で表現）
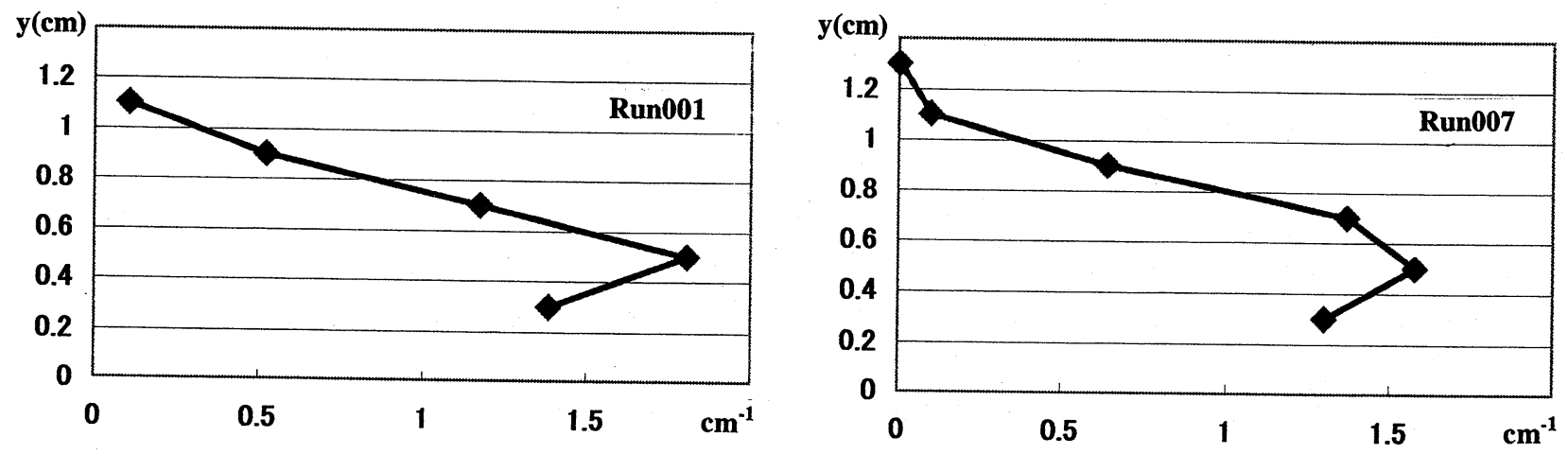

图-4 粒子衝突事象の高さ方向確率密度分布 

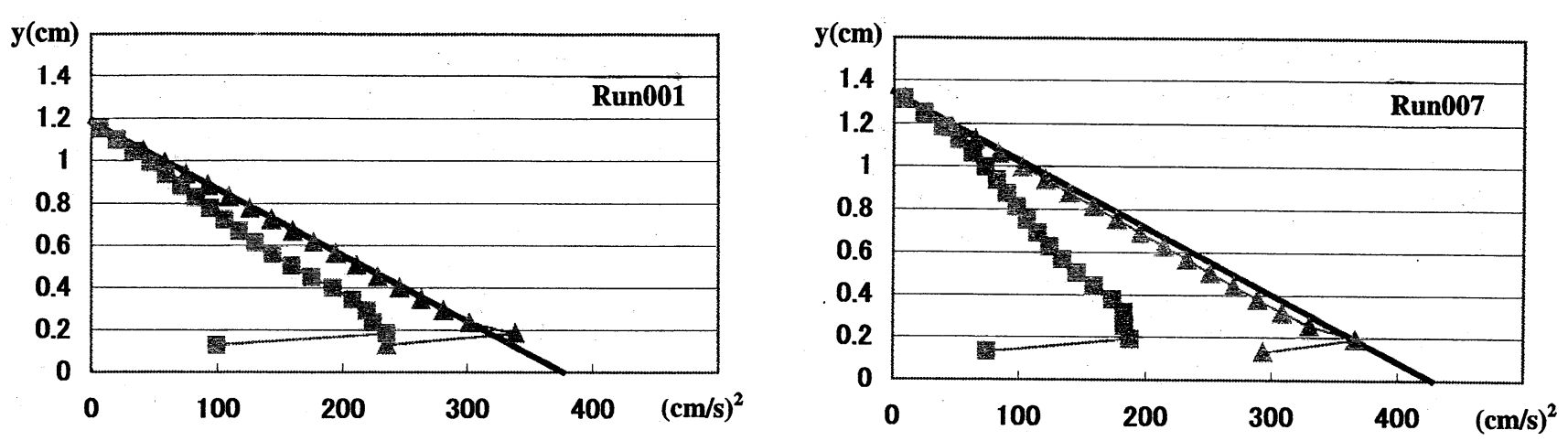

図-5 計算されたレイノルズ応カ $(\boldsymbol{\square})$ と形状抵抗の積分值(A)（伊藤の実験と比較）

粒子速度分布, 衝突事象を頻繁にうける粒子運動と言っ た流砂素過程を求めるツールの可能性を示した. さらに, 流体場の乱れ, 粒子形状抵抗の積分值が応力の分担(内 部構造)にとって重要なことを指摘した. ただし, 本文 中にも指摘したように, DEMパラメタ值同定の仕方と モデルパラメタの素過程への感度分析の課題が残る。ま た，平衡場に限らず，土石流に関しては連続体力学から のアプローチにより多くの成果も得られている。こうし た知見とDEMカップリングモデルとの整合性もつめな ければならない. 本研究を進めるにあたり, 詳細な実験 結果を快く提供して頂いた立命館大学講師伊藤隆郭氏に 感謝いたします。

\section{参考文献}

1）例えば, 江頭進治 : 土石流の流動機構と汇濫・堆積 域の解析（基礎理論からハザードマップまで），土木 学会, 第35回水工学に関する夏季研修会講義集, $\mathrm{A} \beth$ 一ス, A-6-1 A-6-18,1999.

2）後藤仁志 - 辻本哲郎 - 中川博次 : 流体 - 粒子相互作 用系としての掃流層の数值解析, 土木学会論文集, No.485?II-26, pp.11-19, 1994.

3）後藤仁志・Abbas YEGANEH-BAKHTIARY・酒井哲 郎 : 混相流モデルと個別要素法の融合による高濃度掃 流層の数值解析, 土木学会論文集, No.649/II-51,pp.1726,2000.

4) Cundall, P.A. (1979) : A discrete numerical model for granular assemblies, Geotechnique, Vol. 29, No.1, pp.47-65.

5）後藤仁志・酒井哲郎 : 表層せん断を受ける砂層の動 的举動の数値解析, 土木学会論文集, No.521/II32,pp.101-112,1995.

6）後藤仁志 - 酒井哲郎 : 河床構成粒子群との相互作用 を考慮した流砂の流動過程の数值解析, 水工学論文集, 第41巻, pp.819-824,1997.

7）後藤仁志・原田英治・酒井哲郎 : 数值移動床による 混合粒径流砂の流送過程のシミュレーション, 水工学 論文集, 第44巻, pp.665-670,2000.

8）原田英治・後藤仁志 - 酒井哲郎 - 羽間義晃 : 混合粒
径砂の動的粗粒化過程の数值解析, 水工学論文集, 第 45巻, pp.655-660,2001.

9）清水義彦・辻本哲郎 - 中川博次 : 直立性植生層を伴 う流れ場の数値計算に関する研究，土木学会論文集, 第447号/II-19,pp.35-44,1992.

10）辻本哲郎・赤城里至 : 不規則跳躍モデルとk- $モ$ モデ ルを用いた飛砂の運動と風の解析, 海岸工学論文集, 第41巻, pp.386-390,1994.

11）伊藤隆郭 : 土石流の構成即およびその適用に関する 研究, 立命館大学学位論文, p.56, 2000.

12) Bagnold., R. A. :Experiments on a gravity free dispersion of large solid sheres in a Newtonian fluid under shear, Pro. Roy. Soc. A, Vol.225, pp.46-63, 1954.

13）高橋 保 : 土石流の発生と流動に関する研究, 京都 大学防災研究所年報,第20号B-2, pp.405-435,1977.

14）椿東一郎・橋本晴行・末次忠司 : 土石流における粒 子間応力と流動特性, 土木学会論文報告集, 第317号, pp.79-81, 1982.

15）橋本晴行・椿東一郎・平野宗夫 : 土砂の掃流状集合 流動について, 水理講演会論文集, 第30回, pp.235240,1986.

16）江頭進治・芦田和男 - 矢島啓・高濱淳一郎 : 土石流 の構成則に関する研究, 京都大学防災研究所年報,第 32号B-2, pp.487-501,1989.

17）江頭進治・芦田和男・高濱淳一郎・田野中新 : エネ ルギー散逸機構に基づく流砂モデル, 京都大学防災研 究所年報,第33号B-2, pp.293-306,1990.

18）宮本邦明：Newton流体を含む粒子流の流動機構に 関する基礎的研究，立命館大学学位論文，1985.

19）江頭進治・宮本邦明・伊藤隆郭：掃流砂に関する力 学的解釈, 水工学論文集, 第41巻, pp.789-794,1997.

20）後藤仁志・辻本哲郎・中川博次 : 掃流層における粒 子間衝突の流動機構に果たす役割, 土木学会論文集, No.515/II-31,pp.23-32,1995. 